\title{
First records of the invasive spider Badumna longinqua (L. Koch) (Desidae) in southern Brazil with notes on the habitats and the species' dispersion
}

\author{
Miguel Simó $^{1 *}$, Álvaro Laborda ${ }^{1}$, Martín Núñez $^{2}$ and Antonio D. Brescovit ${ }^{3}$ \\ 1 Sección Entomología, Facultad de Ciencias, Universidad de la República, Iguá 4225, CP 11400, Montevideo, Uruguay \\ 2 Centro Universitario Rivera, Ituzaingó 667, CP 40000, Rivera, Uruguay \\ 3 Laboratório Especial de Coleções Zoológicas, Instituto Butantan, Av. Vital Brazil, 1500, CEP 05503-900, São Paulo, SP, Brazil \\ * Corresponding author. E-mail: simo@fcien.edu.uy
}

\begin{abstract}
The invasive species Badumna longinqua and the family Desidae are recorded for the first time for Brazil. The spiders were collected in urban habitats of two cities from the state of Rio Grande do Sul in southern Brazil. Specimens and their webs were found in public parks, window frames and in a cemetery. The absence of this species along a national highway route and its dispersion in Brazil are discussed.
\end{abstract}

Key words: alien spider, synanthropy, South America

Since transoceanic expeditions and the migration of people to urban centers began, anthropic activities have increased, resulting in modification of natural environments all over the world. With this migration, many organisms were dispersed beyond their natural distributional range and into new habitats. Today, trade and globalization are the two most important events for the dispersion of alien species in the world (Kobelt and Nentwig 2008). Spiders are a megadiverse group that includes several invasive species. One of these, Badumna longinqua (L. Koch, 1867), is a medium-sized spider that has been introduced to several parts of the world. This synanthropic species is native to Australia but has colonized New Zealand, America, Japan and Europe (World Spider Catalog 2014), especially in the last decades as a result of human transport and trade (Main 2001; Simó et al. 2011; Pompozzi et al. 2013). The species is common in urban habitats and agroecosystems but mainly in temperate zones of the world. It is a cribellate spider that constructs a conspicuous sticky space or sheet webs that connect with a tubular retreat (Main 2001). This species belongs to the family Desidae, a heterogeneous group of small to large-sized ecribellate and cribellate spiders with a taxonomic status that is not well defined. The family is composed of 182 species in 38 genera and mostly distributed in Australia, New Zealand and the Afrotropical Region (Ubick 2005; Jocqué and Dippenaar-Schoeman 2007; World Spider Catalog 2014). In South America, B. longiqua was reported for the first time from Uruguay (Costa 1993) and recently it was recorded from Argentina (Pompozzi et al. 2013). Both of these records are associated with the species' dispersal using transportation routes (highways) (Simó et al. 2011); this has allowed us to predict the presence of $B$. longinqua in other countries of South America. In this paper, we present the first records of $B$. longinqua and the family Desidae in Brazil.

Considering the presence of this spider along highways and in urban centers in Uruguay and Argentina, two countries neighboring Brazil (Simó et al. 2011; Pompozzi et al. 2013), a field trip was done along a national highway route between Santana do Livramento to Rosário do Sul, in the state of Rio Grande do Sul, southern Brazil. Collections were made at 12 sites along $108 \mathrm{~km}$ of this route. Traffic signs and the bark of Eucalyptus spp. were examined on either side of the roadway; public parks in urban centers were also explored. Specimens were captured by hand, fixed in alcohol, and deposited in the arachnological collections of the Instituto Butantan, São Paulo, Brazil (IBSP) and the Facultad de Ciencias, Universidad de la República, Montevideo, Uruguay (FCE-Ar). A map with the sites surveyed was made using SimpleMappr (Shorthouse 2010).

Badumna longinqua was recorded from the two urban centers visited (Figure 1). In Santana do Livramento, specimens and webs were very frequent at several sites within the city; habitats included doors and windows frames, under park benches, and in phone boxes. At the other urban center visited, Rosário do Sul, the species was not observed in those habitats but it was highly abundant in a cemetery. There, they were

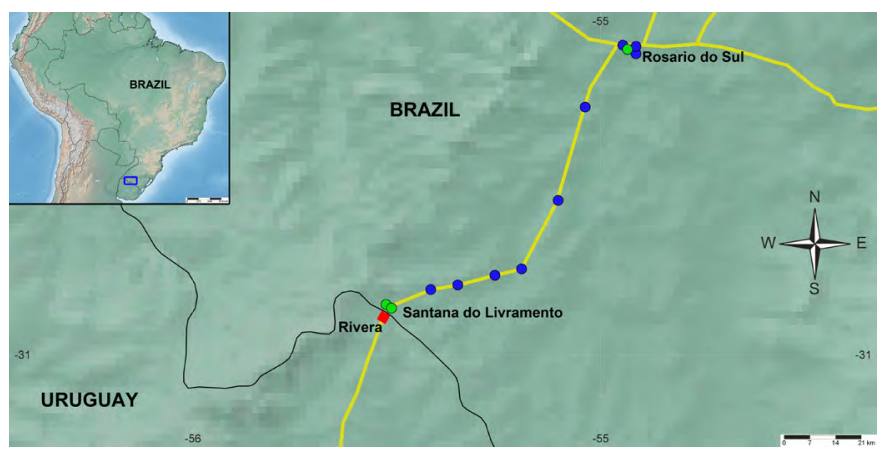

Figure 1. Records of Badumna longinqua in Rio Grande do Sul, Brazil. Green circles: present. Blue circles: absent. Red rectangle: Rivera city, Uruguay. 

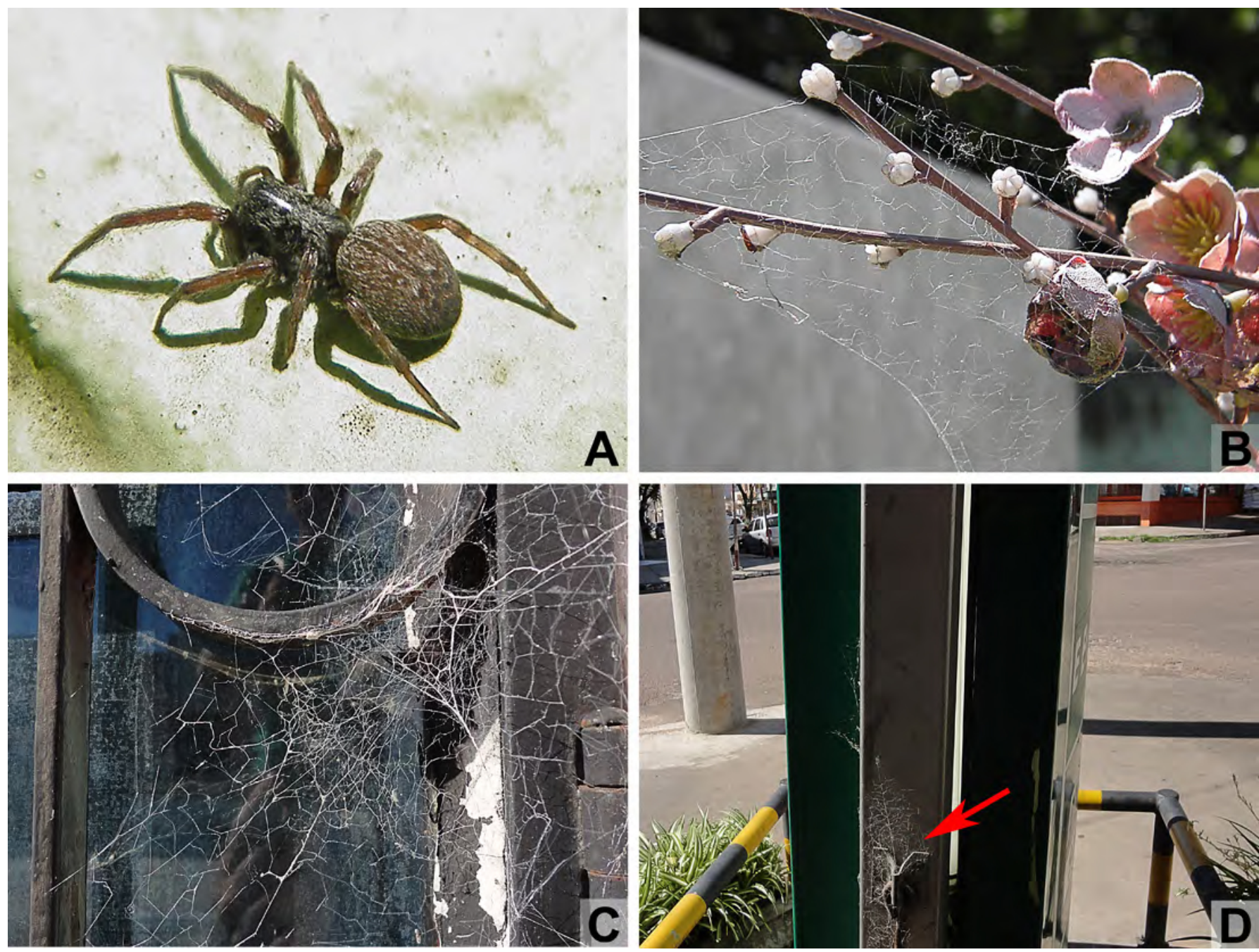

Figure 2. Badumna longinqua in Brazil. Live habitus of female from Rosario do Sul (a). Webs and retreat. Rosario do Sul cemetery: in artificial flowers (b), in a crypt (c). Santana do Livramento: on traffic signs along the side of the roadway (d).

frequently observed in artificial flowers and constructions as buildings (Figure 2). The species was not found in 7 sampling sites along the route that connects Santana do Livramento with Rosário do Sul (Figure 1). Instead, we observed specimens and webs of Metepeira sp. (Araneidae), Metaltella sp. (Amphinectidae) and the synanthropic Kukulcania hibernalis (Hentz, 1842) (Filistatidae); these species occupied the traffic signs and were also found under Eucalyptus spp. bark on the sides of the road (FCE-Ar 480o; 4801).

VOUcher MATERIAL: Rio Grande do Sul. Rosário do Sul. Cemitério São Sebastião (54.929528 $\left.\mathrm{W}, 030.248417^{\circ} \mathrm{S}\right): 28$ October 2013, 1 đ, 10 \%, 12 immature, M. Simó, A. Laborda and M. Núñez collectors (FCE-Ar 4804); with same data, 2 ô, 10 \% (IBSP 165432). Santana do Livramento (55.531545 W, o30.889471 ${ }^{\circ}$ S): 23 June 2013, 1 \&, 1 immature, M. Núñez collector (FCE-Ar 4816). Praça General Osório (55.531056 $6^{\circ} \mathrm{W}$, $030.889194^{\circ}$ S): 28 October 2013, 1 \% , M. Simó, A. Laborda and M. Núñez collector (IBSP 165431).

Santana do Livramento, is a neighbor city to Rivera, Uruguay, where $B$. longinqua was previously recorded (Simó et al. 2011) (Figure 1). Both cities are urban centers that are highly connected by roads, people, and trade, and in both cities, $B$. longinqua occurs abundantly in similar habitats: public parks, around houses, on tree trunks, and traffic signs on the street sidewalks. At Rosário do Sul, this study only recorded $B$. longinqua from the town cemetery. The notable presence of this species in artificial flowers suggests that they are very suitable refuge. Furthermore, cemeteries are places where insects proliferate (Vezzani et al. 2001) allowing to have abundant food for the spider.

In contrast to what was expected, the species was not found in traffic signs or on the bark of Eucalyptus spp. along the route that connects Santana do Livramento with Rosário do Sul. In Uruguay, these habitats were occupied by the species and contributed to its dispersion via human transport (Simó et al. 2011). The presence of B. longinqua along routes is associated with transportation and traffic signs that were placed many years ago in this area (Simó and Laborda pers. obs.). The absence of $B$. longinqua at some sites could be explained by competitive exclusion with other spider species or because environmental conditions are not good for its establishment. In other words, the activities of humans are not sufficient for the spider to live there. In this regard, the occurrence of two localities more than $100 \mathrm{~km}$ apart corroborate the ability of this species to disperse between urban centers as was indicated for other parts of the world (Simó et al. 2011). Furthermore, in Rosário do Sul, the species was only recorded in a cemetery but it was not present in same 
habitats where it was observed in Santana do Livramento. Our results show that $B$. longinqua is dispersing into Brazil and the lower presence in Rosário do Sul could be because it has only just recently dispersed to that city. Furthermore, this study provided information about new sites where the species could live and proliferate in urban centers (e.g., cemeteries). We expect that the dispersion of $B$. longinqua will continue to other areas of southern Brazil. Appropriate habitats in other cities and agroecosystems, and along other routes, should be surveyed in order to monitor the dispersion of this alien species in Brazil.

\section{ACKNOWLEDGMENTS}

To A. Aisenberg and R. Forsyth for their useful comments and revision of the English version of the manuscript. This study was financially supported by CNPq (301776/2004-0) grant to $\mathrm{ADB}$.

\section{LITERATURE CITED}

Costa, F. 1993. Cohabitation and copulation in Ixeuticus martius (Araneae, Amaurobiidae). Journal of Arachnology 21: 258-26o (http://www. americanarachnology.org/JoA_tocs/JOA_contents_v21n3.html).

Jocqué, R. and A.S. Dippenaar-Schoeman. 2007. Spider Families of the World. Belgium, Peteers nv. Royal Museum for Central Africa. 336 pp.

Kobelt, M. and W. Nentwig. 2008. Alien spider introductions to Europe supported by global trade. Diversity and Distributions 14(2): 273-28o (doi: 10.1111/j.1472-4642.2007.00426.x).

Main, B.Y. 2001. Historical ecology, responses to current ecological changes and conservation of Australian spiders. Journal of Insect Conservation 5: 9-25 (doi: 10.1023/A:1011337914457).
Pompozzi, G., L. Peralta and M. Simó. 2013. The invasive spider Badumna longinqua (L. Koch, 1867) (Araneae: Desidae) in Argentina: new distributional records, with notes on its expansion and establishment. Check List 9(3): 218-221. (http:// www.checklist.org.br/archive?vol=9\&num=3).

Simó, M., A. Laborda, C. Jorge, J.C. Guerrero, M. Alves Dias and M. Castro. 2011. Introduction, distribution and habitats of the invasive spider Badumna longinqua (L. Koch, 1867) (Araneae: Desidae) in Uruguay, with notes on its world dispersion. Journal of Natural History 45 (27): 1637-1648. (doi: 10.1080/00222933.2011.559599).

Shorthouse, D.P. 2010. SimpleMappr, an online tool to produce publication-quality point maps. Accessible at: http://www. simplemappr.net. Captured on 7 February 2014

Ubick, D. 2005. Family Desidae; pp. 93-94, in: Ubick, D., P. Paquin, P. Cushing and V. Roth (eds). Spiders of North America. An Identification Manual. New York: American Arachnological Society.

Vezzani, D., S.M. Velázquez, S. Soto and N.J. Schweigmann. 2001. Environmental characteristics of the cemeteries of Buenos Aires city (Argentina) and infestation levels of Aedes aegypti (Diptera: Culicidae). Memórias do Instituto Oswaldo Cruz 96(4): 467-471 (doi: 10.1590/So074-02762001000400005).

World Spider Catalog. 2014. World Spider Catalog. Version 15.5. Natural History Museum Bern. Accessible at: http://wsc.nmbe. ch. Captured on 21 November 2014.

Authors' contribution statement: $\mathrm{MS}$ and $\mathrm{ADB}$ conceived the paper. MS, AL and MN conducted the field work. AL prepared the figures. MS, ADB and AL finalized the manuscript.

Received: June 2014

Accepted: December 2014

Editorial responsibility: Ana Lúcia Tourinho 